\title{
A Climate Trend Analysis of Senegal
}

\section{Conclusions}

- Summer rains have remained steady in Senegal over the past 20 years but are 15 percent below the 1920 1969 average.

- Temperatures have increased by $0.9^{\circ}$ Celsius since 1975, amplifying the effect of droughts.

- Cereal yields are low but have been improving.

- The amount of farmland per person is low and declining rapidly.

- Current population and agriculture trends could lead to a 30 percent reduction in per capita cereal production by 2025.

\section{Food Security Context}

Senegal (area: 196,722 square kilometers) is bounded by the Atlantic Ocean, Mauritania, Mali, Guinea, and Guinea-Bissau. The Gambia is almost entirely surrounded by Senegal and shares 740 kilometers of common border. Senegal's population, estimated at 13.0 million in 2011 , is about 58 percent rural. The annual population growth rate is 2.5 percent (CIA, 2011), with an estimated doubling time of 27 years. Agriculture employs 77 percent of the economically active populace and accounts for 12.4 percent of the gross domestic product. Agriculture is mainly rainfed and depends heavily upon the seasonal rainfall amounts and distribution. Food staples - millet, sorghum, maize, and rice - are grown for domestic consumption, and cotton and groundnut are grown for export. Crop production is subject to drought and threats from pests such as desert locusts. Senegal is a net importer of cereal crops. The northern part of Senegal is characterized by greater rainfall variability, the least diversified rainfed agriculture, and extensive herding that is relatively more important than crop production. This region is the most affected by drought, and its population is often exposed to food insecurity.

This brief report, drawing from a multiyear effort by the U.S. Agency for International Development (USAID) Famine Early Warning Systems Network (FEWS NET), examines recent trends in rainfall and air temperatures. These analyses are based on quality controlled station observations.

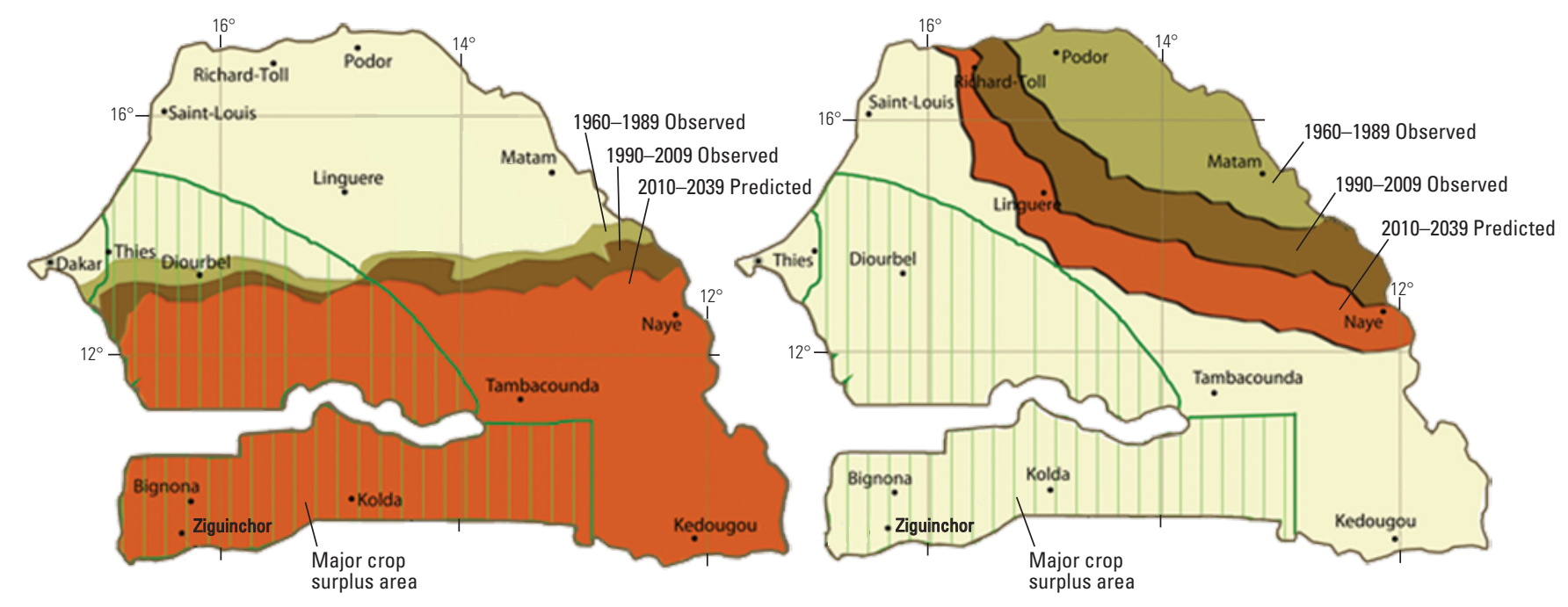

Figure 1. Climate change in Senegal: The left map shows the average location of the June-September 500-millimeter rainfall isohyets for 1960-1989 (light brown), 1990-2009 (dark brown), and 2010-2039 (predicted, orange). The green polygons in the foreground show the main crop surplus regions for millet and maize. The right map shows analogous changes for the June-September 30 degrees Celsius air temperature isotherms. 


\section{Rainfall Remains Below Normal}

Rainfall in Senegal declined rapidly between 1950 and the mid-1980s, and partially recovered in the 1990s. Between 2000 and 2009, however, the recovery slowed, and the 2000-2009 mean remained about 15 percent lower than the 1920-1969 mean. The post-1980s rainfall increases are probably due to the warming of the north Atlantic Ocean (Hoerling and others, 2006); as the northern tropical Atlantic has increased in temperature over this period, this has drawn the summer rains further north, increasing rainfall in the Sahel. These rainfall changes can be visualized in three ways: as a reduction of the areas receiving adequate rainfall for viable agricultural livelihoods, as maps of anticipated changes in rainfall, and as time series plots.

Senegal receives most of its rain between June and September, and rainfall totals of more than 500 millimeters $(\mathrm{mm})$ during this season typically provide enough water for crops and livestock. Between 1960 and 1989, the region receiving (on average) this much rain during June-September is shown in light brown in the left panel of figure 1 and should be understood to lie beneath the dark brown and orange areas. During the past 20 years, this region has retreated southward by about 30 kilometers, in a line roughly even with Dakar, the capital city. This retreat has likely affected the important crop growing regions near the cities of Thies and Diourbel, an important peanut growing region (see the Objectives and Methods section for place names mentioned here). In the east of the country, the $500 \mathrm{~mm}$ contour has retreated across a region categorized by sylvo-pastoralist livelihoods.

Rainfall reductions and temperature increases can be visualized by combining the observed 1960-2009 changes with predicted 2010-2039 changes, based on persistence of the observed trends (fig. 2, top panels). Rainfall decreases range from - 150 to $-50 \mathrm{~mm}$ across much of the country; the western and eastern portions of the country remain substantially below the 1960 1989 average. The western regions of reduced rainfall coincide with the densely populated regions of Thies, Diourbel, and Kaolack (see the Objectives and Methods section for population totals and region names). Observed changes (those occurring between 1960 and 2009) account for 63 percent of the change magnitudes. A second area of substantial rainfall declines lies in the southeast of the country, in the Tambacounda region.

Smoothed time series (fig. 2, lower panel, 10-year running means) of 1900-2009 rainfall, extracted for crop growing regions in Senegal, show that rainfall recovered since the mid-1980s but has not increased over the past decade, and 2000-2009 rainfall remains substantially (15 percent) below the 1920-1969 mean. These time series were based on crop growing regions in central and northern Senegal (Thies, Diourbel, Matam, Fatick, and Kaolack) and southern Senegal (Tambacounda and Kolda). The Objectives and Methods section has a population map with region names.

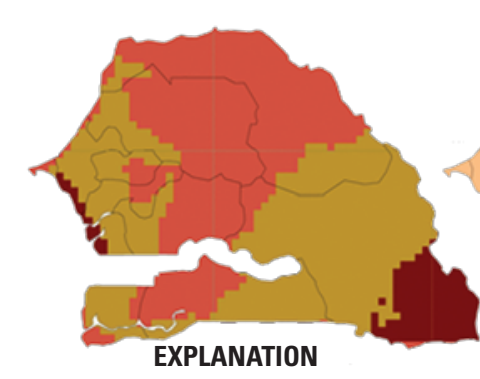

Change in rainfall, in millimeters Less than $-150 \square$ Less than -10 Less than -50

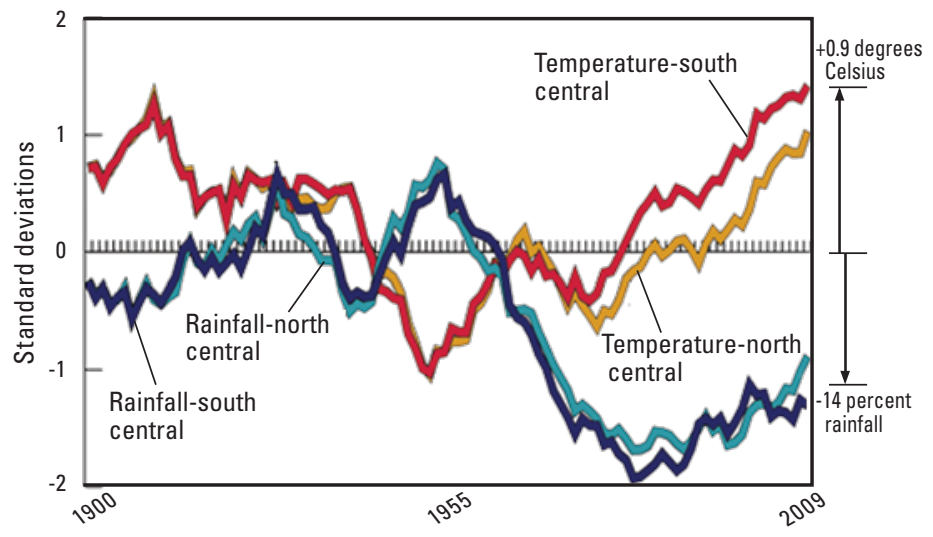

Figure 2. Observed and projected change in June-September rainfall and temperature for 1960-2039 (top), together with smoothed rainfall and air temperature time series for June-September for southern and north-central Senegal (bottom). Mean rainfall and temperature are based on the 1920-1969 time period.

\section{Much Warmer Air Temperatures}

Since 1975, temperatures have increased by almost $0.9^{\circ}$ Celsius $\left({ }^{\circ} \mathrm{C}\right)$ across much of Senegal. This transition to an even warmer climate could reduce crop harvests and pasture availability, amplifying the impact of droughts. Assuming the observed trends persist, we can create a composite of observed and anticipated air temperature changes (fig. 2, top right panel). Again, observed changes alone account for 63 percent of the change magnitudes. Senegal is becoming substantially hotter. Time series of air temperature data (fig. 2, lower panel) show that the magnitude of recent (post-1975) warming is large and unprecedented within the past 110 years. We estimate that the 1975 to 2009 warming has been more than $0.7^{\circ} \mathrm{C}$ for Senegal during the June-September rainy season. Given that the standard deviation of annual air temperatures in these regions is low $\left(0.4^{\circ} \mathrm{C}\right)$, these increases represent a very large $(+1.2$ standard deviations) change from the climatic norm. Such warming, in regions with very high average air temperatures, can amplify the impact of water shortages. 


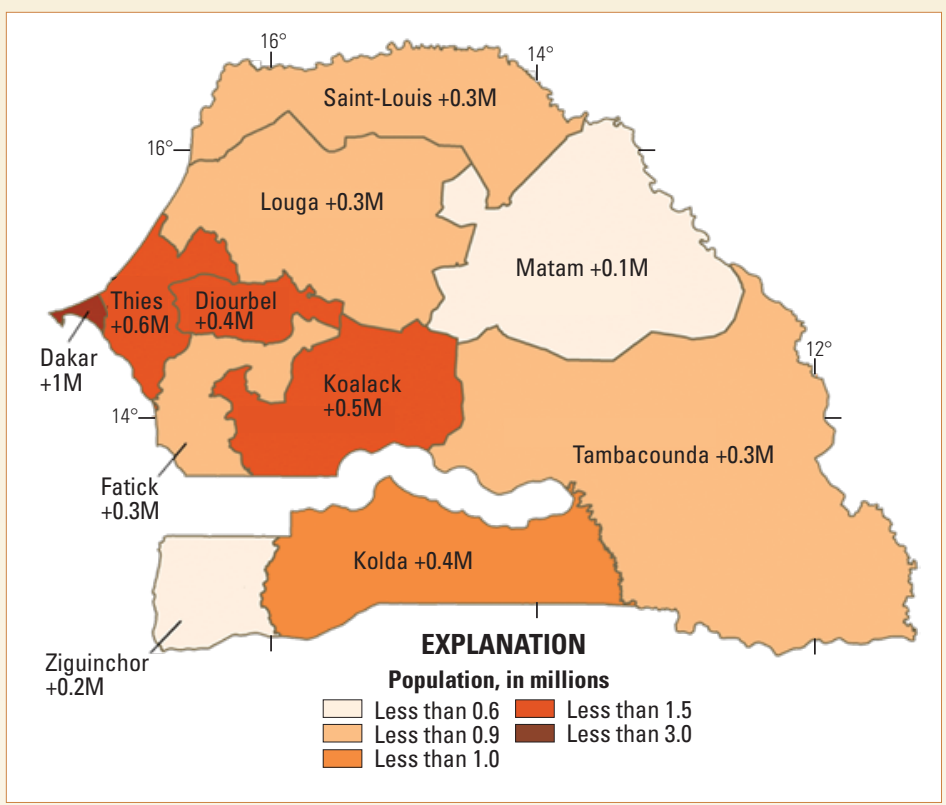

Figure 3. Landscan 2008 population (ORNL, 2010) for Senegal along with Gridded Population of the World estimates (CIESIN, 2010) of 1990 to 2010 population change in millions of people.

\section{Population Growth Has Not Been Matched by Agricultural Development}

In 2011, the estimated population of Senegal was 13.0 million (CIA, 2011). Senegal has a population growth rate of 2.5 percent; at this rate the population will double every 27 years. Between 1990 and 2010, the population of Senegal increased 64 percent, with the largest increases in population (fig. 3) occurring in Dakar (+1 million), Thies ( +0.6 million), and Kaolack ( +0.5 million). This population expansion will place increasing stress on limited natural resources. Analysis of crop statistics from the Food and Agriculture Organization of the United Nations (FAO, 2011) suggests that increases in crop yields have not kept pace with population growth. Between the 1960s and 2000s, the amount of farmland per person has declined by 300 percent (from $\sim 0.3$ hectares per person to $\sim 0.1$ hectares per person), while yields have only increased by $\sim 70$ percent. A continuation of these trends will be unfavorable for national food security; projections for 2025 based on these trends suggest that Senegal will produce 30 percent less cereal crops per person.

\section{Some Implications For Food Security and} Adaptation

The results presented here depict a combination of recent rainfall variations and air temperature increases. While the rainfall increases from the 1980s to 1990s helped improve yields, these yield increases have been offset by large declines in the amount of farmland per person. For the past 10 years, however, rainfall has remained steady, and it remains to be seen if the earlier rainfall increases will persist. The sea surface temperature gradient of the Atlantic Ocean swings slowly from north to south on a time scale of decades, and a reversal of the current state could lead to another precipitous Sahelian rainfall decline, a decline augmented by the effects of warmer air temperatures. Given the potential for such a decline, raising yields in wetter areas may be a more viable option than extending agriculture into more marginal areas. The rapid population expansion in Thies, Diourbel, and Kaolack, heavily populated regions that are important crop producing areas, combined with further drying and warming, could lead to increased food insecurity in these regions.

\section{Objectives and Methods}

The FEWS NET Informing Climate Change Adaptation series seeks to guide adaptation efforts by providing subnational detail on the patterns of climate trends already observed in an appropriately documented record. Whether these observed trends are related to natural climate variations, global warming, or some combination of the two is less important than knowing now where to focus adaptation efforts.

These FEWS NET reports rely on rigorous analysis of station data, combined with attribution studies using observed climate data. This brief report examines Senegal rainfall and temperature trends for the last 110 years (1900-2009) using observations from 98 rainfall gauges and 13 air temperature stations for the primary rainy period, June-September. The data were quality controlled, and the mean 1960-1989 and mean 1990-2009 station values calculated. The difference between these means was converted into 1960-2009 trend observations and interpolated using a rigorous geo-statistical technique (kriging). Kriging produces standard error estimates, which can be used to assess the relative spatial accuracy of the identified trends. Dividing the trends by the associated errors allows us to identify the relative certainty of our estimates (Funk and others, 2005; Verdin and others, 2005; Brown and Funk, 2008; Funk and Verdin, 2009; Funk and others, 2012). Readers interested in more information can find these publications at http://earlywarning.usgs.gov/fews/reports.php.

This report was written by Chris Funk (USGS), Jim Rowland (USGS), Alkhalil Adoum (UCSB), Gary Eilerts (USAID), James Verdin (USGS), and Libby White (UCSB). It builds upon a multiyear research project (see references) carried out under a USAID-funded FEWS NET agreement with USGS. 


\section{References}

Brown, M.E., and Funk, C.C., 2008, Food security under climate change: Science, v. 319, p. 580-581. (Also available online at ftp://chg.geog.ucsb.edu/pub/pubs/Science_2008. $p d f$.)

CIA (Central Intelligence Agency), 2011, The World Factbook, accessed December 15, 2011, at https://www.cia.gov/library/ publications/the-world-factbook/geos/sg.html.

CIESIN (Center for International Earth Science Information Network), 2010, Gridded population of the world, version 3, accessed May 5, 2010, at http://sedac.ciesin.columbia.edu/ gpw/.

FAO (Food and Agriculture Organization of the United Nations), 2011, FAOSTAT: Accessed December 15, 2011, at http://faostat.fao.org.

Funk, C., Senay, G., Asfaw, A., Verdin, J., Rowland, J., Korecha, D., Eilerts, G., Michaelsen, J., Amer, S., and Choularton, R., 2005, Recent drought tendencies in Ethiopia and equatorial-subtropical eastern Africa: Washington, DC, U.S. Agency for International Development. (Also available at http://earlywarning.usgs.gov/fews/pubs/FEWSNET_2005. $p d f$.)
Funk C., and Verdin, J.P., 2009, Real-time decision support systems-The Famine Early Warning System Network, in Gebremichael, M., and Hossain, F., eds., Satellite rainfall applications for surface hydrology: Netherlands, Springer, p. 295-320. (Also available online at http:/learlywarning. usgs.gov/fews/pubs/SatelliteRainfallApplications_2010.pdf.)

Funk, C., Michaelsen, J., and Marshall, M., 2012, Mapping recent decadal climate variations in precipitation and temperature across Eastern Africa and the Sahel, chap. 14 in Wardlow, B., Anderson, M., and Verdin, J., eds., Remote sensing of drought-Innovative monitoring approaches: Taylor and Francis, 25 p. (Also available at http://earlywarning.usgs. gov/fews/pubs/mapping_decadal_variations.pdf.)

Hoerling, M., Hurrell, J., Eischeid, J., and Phillips, A., 2006, Detection and attribution of twentieth-century northern and southern African rainfall change: Journal of Climatology, v. 19 , p. $3,989-4,008$.

ORNL (Oak Ridge National Laboratory), 2010, Landscan 2008 population, accessed May 5, 2010, at http://www.ornl.gov/sci/ landscan/.

Verdin, J.P., Funk, C.C., Senay, G.B., and Choularton, R., 2005, Climate science and famine early warning: Philosophical Transactions of the Royal Society B-Biological Sciences, v. 360 , no. 1463 , p. 2,155-2,168. (Also available at http:// earlywarning.usgs.gov/fews/pubs/RoyalSociety.pdf.) 